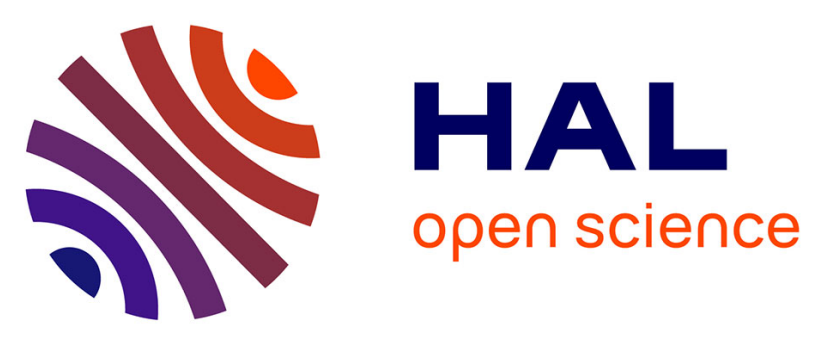

\title{
A mutated thermostable Thermus aquaticus DNA polymerase with reverse transcriptase activity for one step RNA pathogen detection
}

Andreas Marx, Ramon Kranaster, Nicole Engel, Manfred Weidmann, Frank Hufert, Matthias Drum

\section{To cite this version:}

Andreas Marx, Ramon Kranaster, Nicole Engel, Manfred Weidmann, Frank Hufert, et al.. A mutated thermostable Thermus aquaticus DNA polymerase with reverse transcriptase activity for one step RNA pathogen detection. Biotechnology Journal, 2010, 5 (2), pp.224. 10.1002/biot.200900200 . hal-00552334

\section{HAL Id: hal-00552334 \\ https://hal.science/hal-00552334}

Submitted on 6 Jan 2011

HAL is a multi-disciplinary open access archive for the deposit and dissemination of scientific research documents, whether they are published or not. The documents may come from teaching and research institutions in France or abroad, or from public or private research centers.
L'archive ouverte pluridisciplinaire HAL, est destinée au dépôt et à la diffusion de documents scientifiques de niveau recherche, publiés ou non, émanant des établissements d'enseignement et de recherche français ou étrangers, des laboratoires publics ou privés. 
A mutated thermostable Thermus aquaticus DNA polymerase with reverse transcriptase activity for one step RNA pathogen detection

\begin{tabular}{|r|l|}
\hline Journal: & Biotechnology Journal \\
\hline Manuscript ID: & biot.200900200.R1 \\
\hline Wiley - Manuscript type: & Research Article \\
\hline Date Submitted by the & $25-$ Oct-2009 \\
\hline Complete List of Authors: & $\begin{array}{l}\text { Marx, Andreas; University of Konstanz, Konstanz Research School } \\
\text { Chemical Biology } \\
\text { Kranaster, Ramon; University of Konstanz } \\
\text { Engel, Nicole; University of Konstanz } \\
\text { Weidmann, Manfred; University of Goettingen } \\
\text { Hufert, Frank; University of Goettingen } \\
\text { Drum, Matthias; UNiversity of Konstanz }\end{array}$ \\
\hline Main Keywords: & \\
\hline All Keywords: & \multicolumn{2}{|c|}{ Keywords: } & DNA polymerase, RNA pathogen detection, reverse transcription \\
\hline \hline
\end{tabular}

\section{S ScholaroNE \\ Manuscript Central}




\title{
Research Article ((5072 words))
}

\section{A mutated thermostable Thermus aquaticus DNA polymerase with reverse transcriptase activity for one step RNA pathogen detection}

\author{
Ramon Kranaster ${ }^{1}$, Matthias Drum ${ }^{1}$, Nicole Engel ${ }^{1}$, Manfred Weidmann ${ }^{2}$, Frank T. Hufert ${ }^{2}$, \\ and Andreas Marx ${ }^{1, \star}$. \\ ${ }^{1}$ Department of Chemistry and Konstanz Research School Chemical Biology, University of \\ Konstanz, Universitätsstrasse 10, D 78457 Konstanz, Germany \\ ${ }^{2}$ University Medical Center, Goettingen, Department of Virology, Kreuzbergring 57, 37075 \\ Göttingen
}

Keywords: DNA polymerase, RNA pathogen detection, reverse transcription, RT - PCR, RNA-secondary structures, G-Quadruplex

Correspondence: Prof. Dr. Andreas Marx, Department of Chemistry, Konstanz Research School Chemical Biology, University of Konstanz, Universitätsstrasse 10, D 78457 Konstanz, Germany

Email: andreas.marx@uni-konstanz.de

Tel.: +49 7531885139

Fax: +497531885140

Abbreviations: CP, Crossing points; Ct, threshold-crossing points; dNTPs, deoxynucleotide triphosphates; E. coli, Escherichia coli; KlenTaq, N-terminal shortened form of a DNA polymerase from Thermus aquaticus; PAGE, polyacrylamide gel electrophoresis; PCR, polymerase chain reaction; RT, reverse transcription; Taq M1, mutated DNA polymerase from Thermus aquaticus; Tth Thermus thermophilus. 


\begin{abstract}
We describe the cloning and characterisation of a mutated thermostable DNA polymerase from Thermus aquaticus (Taq) which exhibits an increased reverse transcriptase activity and is therefore designated for one step PCR pathogen detection using established real-time detection methods. We demonstrate that this Taq polymerase mutant (Taq M1) has similar PCR sensitivity and nuclease activity as the respective Taq wild-type DNA polymerase. In addition and in marked contrast to the wild-type, Taq M1 exhibits a significantly increased reverse transcriptase activity especially at high temperatures $\left(>60^{\circ} \mathrm{C}\right)$. RNA generally hosts highly stable secondary structure motifs such as hairpins and G-quadruplexes which complicate or in the worst case obviate reverse transcription (RT). Thus, RT at high temperatures is desired to weaken or melt secondary structure motifs. To demonstrate the ability of Taq M1 for RNA detection of pathogens we performed TaqMan probe-based diagnostics of Dobrava viruses by one step RT-PCR. Indeed, we found similar detection sensitivities compared to commercial available RT-PCR systems without further optimization of reaction parameters thus making this enzyme highly suitable for any PCR probe based RNA detection method.
\end{abstract}




\section{Introduction}

Emerging viral pathogens such as athropod-borne Flavi- and Alphaviruses or rodentborne Hantavirus [1] or the recently occurring Influenza A virus subtype H1N1 [2] are a constant threat to global public health [3]. To monitor and detect their appearance and circulation reliable pathogen detection methods are necessary. Apart from several antibody based assays [4] like the hemagglutination inhibition test $(\mathrm{HI})$, enzyme immunoassay (EIA), and virus neutralization tests (VN), nucleic acid detection assays (NA) such as the polymerase chain reaction (PCR) are among the most reliable detection techniques used for pathogen detection [5]. For PCR a DNA polymerase needs specific primers (short DNA fragments) with sequences complementary to a target DNA region. During repeated cycles of heating and cooling new DNA is generated and is itself used as a template for replication. Due to the enzymatic replication under consumption of the primers and deoxynucleotide triphosphates (dNTPs), the selected DNA sequence framed by the primers is exponentially amplified in theory. Almost in every PCR applications heat-stable DNA polymerases are employed which remain active during the thermal cycling steps necessary to physically separate the two strands of the DNA double helix (usually at high temperatures $\sim 95^{\circ} \mathrm{C}$ ). Nowadays real-time PCR methods using unspecific fluorescent dyes, e. g. SYBRgreen I or specific probes e.g. TaqMan probes [6-9], report the amount of amplified DNA in real-time and have significantly shortened conventional PCR methods. Consequently, they are the method of choice for detection and quantification of DNA and RNA targets such as retroviruses and viral pathogens [9]. In routine molecular diagnostics probe based real time PCR systems are state of the art since they are highly sensitive and include a specificity control. Two enzymes are needed to detect RNA by a reverse transcription (RT)-PCR. In a first crucial step for RT-PCR, the RNA target is reverse transcribed into the Wiley- ${ }^{4} \mathrm{CH}$ 
complementary DNA strand. This is performed by a non-thermostable RNAdependent DNA polymerase (reverse transcriptase) followed by real-time amplification of the transcribed target by a thermostable DNA polymerase [9]. In real time RT-PCR, fluorescent probes are used to increase the level of specificity and to avoid detection of non-specific side-products $[6,7,10]$ : The fluorescent probe hybridises to a sequence in-between the flanking primer sequences of the PCR target. In a TaqMan probe fluorophor and a quencher molecule are covalently attached to the 5' and 3' end of the probe allowing for Förster resonance energy transfer (FRET) to occur between both dye molecules, resulting in suppressed fluorescence of the fluorophor dye. During the PCR extension steps, a DNA polymerase, which harbours an active nuclease domain, degrades the DNA stretch of fluorescence probe that is annealed to the target strand. The fluorophor molecule is cleaved from the probe and released from close proximity to the quencher molecule, resulting in increased fluorescence. Thus, the generated fluorescence signal is directly proportional to the amplified target molecules after each cycle. The most critical step in this method is the conversion from the RNA target into DNA. This reverse transcription is prone to failure, because RNA often hosts highly stable secondary structure motifs such as hairpins and G-quadruplexes that complicate or even prevent reverse transcription [11]. Thus, thermostable reverse transcriptases, which are able to work at higher temperatures, are of urgent need to increase reliability and sensitivity of RNA pathogen detection systems. It is known that some DNA polymerases for example from Thermus aquaticus exhibit a low intrinsic RT activity that is too inefficient for a fast and reliable RT-PCR based RNA detection [12]. Myers and Gelfand [11] reported a DNA polymerase from Thermus thermophilus (Tth) that exhibits increased RT activity exclusively in the presence of $\mathrm{Mn}^{2+}$ ions, but 
unfortunately for many biotechnological applications like pathogen detection or gene expression analysis, employment of $\mathrm{Mn}^{2+}$ is inappropriate [9].

We previously evolved a $\mathrm{N}$-terminal shortened form of a DNA polymerase from Thermus aquaticus (KlenTaq) with increased reverse transcriptase activity [13]. In order to investigate whether the full-length Taq DNA polymerase mutant (henceforth called Taq M1) including the nuclease domain would be applicable in real time one step detection of pathogenic DNA using TaqMan probes, we fused the nuclease domain to the prior generated mutant KlenTaq. We demonstrate the successful generation of the nuclease activity under conservation of the previously evolved reverse transcriptase activity. Our results show that Taq M1 has similar PCR sensitivity and nuclease activity as the respective wild-type Taq DNA polymerase however, exhibits reverse transcriptase ability. In addition, we demonstrate the usefulness of Taq M1 for fast and reliable RNA pathogen detection in a case study for the detection of RNA from Dobrava virus and its advantages in RT-PCR using RNA targets that form stable secondary structure motifs.

\section{Materials and methods}

\subsection{Reagents and Instruments}

Oligonucleotides were purchased from Purimex or Metabion, Germany. High Pure PCR Cleanup Micro Kit, High Pure Plasmid Isolation Kit, and RNA from Bacteriophage MS2 were from Roche. RNeasy Mini Kit and QIAquick Gel Extraction Kit were purchased from Qiagen. PageRuler unstained Protein Ladder, DNasel, RiboLock $^{T M}$ RNase Inhibitor and Rapid DNA Ligation Kit were purchased from Fermentas. Real-time PCR was performed in iCycler or Chromo4 instrument from BioRAD. SYBRgreenl was purchased from Molecular Probes. Denaturing PAGE was analysed with a Molecular Imager Fx from BioRAD. Phusion DNA polymerase, 
Antarctic Phosphatase, Low MW ladder, EcoRV, and BsmBI were purchased from New England Biolabs.

\subsection{Cloning, Protein Expression and Purification of Taq M1 Polymerase}

Respective plasmids (pASK-IBA37plus) harbouring KlenTaq M1 and Taq wild-type gene were isolated from the respective E. coli cultures using the High Pure Plasmid Isolation Kit. The KlenTaq M1 polymerase gene [14] was amplified by using Phusion DNA polymerase with the forward primer (5'-GAT CTA CGT CTC CGC CCT GGA GGA GGC CC-3') and reverse primer (5'-CAG GTC AAG CTT AGT TAG ATA TCA CTC C-3'). Taq nuclease domain DNA [15] including the whole pASK-IBA37plus plasmid sequence was amplified by using Phusion DNA polymerase with the forward primer (5'-GCC AAG GAG TGA TAT CTA ACT AAG CT-3') and reverse primer (5'ATG ATC CGT CTC AGG GCC TTG GGG CTT TCC AGA A-3'). Both amplificates were purified by $0.8 \%$ agarose gel and isolated using the QIAquick Gel Extraction Kit. Isolated DNA was digested by EcoRV and BsmBI, purified using the High Pure PCR Cleanup Micro Kit. The Taq nuclease domain amplificate was dephosphorylated using Antarctic Phosphatase and ligated with the KlenTaq amplificate by using the Rapid DNA Ligation Kit and transformed into electro competent E. coli XL10 gold cells. Clones were picked from agar plates and separately grown overnight in LB medium (100 $\mathrm{mg} / \mathrm{ml}$ carbenicillin). Integrity of whole mutant clone was proved by sequencing of the respective purified plasmid (GATC Biotech AG, Germany) using the sequencing primers p1 - p5 (p1 5'-GAG TTA TTT TAC CAC TCC CT-3', p2 5'CCT GGC TTT GGG AAA AG-3', p3 5'-CCC GAG CCT TAT AAA GC-3', p4 5'-CGT AAG GGA TGG CTA GCT CC-3', p5 5'-CGC AGT AGC GGT AAA CG-3'). Enzyme purification and concentration determination was conducted as previously described $[13,16]$ 


\subsection{Assay of nuclease activity}

Reaction mixtures $(60 \mu \mathrm{l})$ contained $50 \mathrm{mM}$ Tris $\mathrm{HCl}(\mathrm{pH} 9.2), 16 \mathrm{mM}\left(\mathrm{NH}_{4}\right)_{2} \mathrm{SO}_{4}$, $0.1 \%$ Tween 20, $2.5 \mathrm{mM} \mathrm{MgCl}_{2}, 50 \mathrm{nM}$ of each dNTP, $150 \mathrm{nM}$ substrate DNA (22 nt, 5'-[ $\left.{ }^{32} \mathrm{P}\right]-C C C$ CCC CCC CTC ATA CGT ACA C-3', 225 nM template DNA (5'-GTG TAC GTA TGA TCA TGC AGG TAG CCG ATG AAC TGG TCG AAA GAC CAG TTC ATC GGC TAC CTG CAT GAT-3'). After an initial denaturation and annealing step $\left(95^{\circ} \mathrm{C}\right.$ for $5 \mathrm{~min}, 0.5^{\circ} \mathrm{C} / \mathrm{s}$ cooling down to $4^{\circ} \mathrm{C}$ ), the reaction mixture was heated to $30^{\circ} \mathrm{C}$ and the reaction was started by addition of DNA polymerase (50 nM final concentration). $5 \mu$ laliquots were taken at various time periods up to $60 \mathrm{~min}$ and reaction was stopped by addition of gel loading buffer $(80 \%$ formamide, $20 \mathrm{mM}$ EDTA). Product mixtures were analysed by $12 \%$ denaturating PAGE and quantified using a Phosphorimager.

\subsection{Real-time PCR, template dilution series}

Reaction mixtures $(20 \mu \mathrm{l})$ contained $50 \mathrm{mM}$ Tris- $\mathrm{HCl}(\mathrm{pH} 9.2), 16 \mathrm{mM}\left(\mathrm{NH}_{4}\right)_{2} \mathrm{SO}_{4}$, $0.1 \%$ Tween 20, $2.5 \mathrm{mM} \mathrm{MgCl}_{2}, 250 \mu \mathrm{M}$ of each dNTP, tenfold dilution series of template RNA from bacteriophage MS2 (10 nM - $10 \mathrm{fM})$ or DNA template MS2 (1 nM - 10 fM, 100 nt, 5'-d(ATC GCT CGA GAA CGC AAG TTC TTC AGC GAA AAG CAC GAC AGT GGT CGC TAC ATA GCG TGG TTC CAT ACT GGA GGT GAA ATC ACC GAC AGC ATG AAG TCC G)-3'), 200 nM of each primer (5'-d(ATC GCT CGA GAA CGC AAG TT)-3' forward, 5'-d(CGG ACT TCA TGC TGT CGG TG)3' reverse), $0.6 \times$ SYBRgreenl, $10 \mathrm{nM}$ Taq DNA polymerase wt / M1 and for the temperature dependence reactions (vide infra) $5 \mathrm{nM}$ enzyme respectively. After an initial reverse transcription cycle $\left(95^{\circ} \mathrm{C}\right.$ for $30 \mathrm{sec}, 55^{\circ} \mathrm{C}$ for $35 \mathrm{sec}$ and $65^{\circ} \mathrm{C}$ for 30 
min) the product was amplified by $30 \mathrm{PCR}$ cycles $\left(95^{\circ} \mathrm{C}\right.$ for $30 \mathrm{sec}, 55^{\circ} \mathrm{C}$ for $35 \mathrm{sec}$ and $72{ }^{\circ} \mathrm{C}$ for $40 \mathrm{sec}$ ) and following melting curve measurement from $30-94^{\circ} \mathrm{C}$. In case of DNA templates the PCR was performed without the RT step. Temperature dependence of reverse transcriptase activity was tested by applying a temperature gradient (from $60-72^{\circ} \mathrm{C}$ for $15 \mathrm{~min}$ ) during the reverse transcription cycle and subsequent amplification as described above.

\subsection{Primer extension assay with an RNA template}

Reaction mixtures $(20 \mu \mathrm{l})$ contained $50 \mathrm{mM}$ Tris $\cdot \mathrm{HCl}\left(\mathrm{pH}\right.$ 9.2), $16 \mathrm{mM}\left(\mathrm{NH}_{4}\right)_{2} \mathrm{SO}_{4}$, $0.1 \%$ Tween 20, $2.5 \mathrm{mM} \mathrm{MgCl}_{2}, 10 \mathrm{nM}$ Taq DNA polymerase wt or M1, $150 \mathrm{nM}$ DNA primer (20 nt, 5'-['32P]-d(CGT TGG TCC TGA AGG AGG AT)-3'), 225 nM template RNA (5'- AAA UCA ACC UAU CCU CCU UCA GGA CCA ACG-3'). After an initial denaturation and annealing step $\left(95^{\circ} \mathrm{C}\right.$ for $2 \mathrm{~min}, 0.5^{\circ} \mathrm{C} / \mathrm{s}$ cooling to $40^{\circ} \mathrm{C}$ for $30 \mathrm{sec}$ ), a temperature gradient (from $60-72^{\circ} \mathrm{C}$, in detail: $60.1,60.3,61.2,62.5,63.9,65.3$, $66.7,68.1,69.5,70.8,71.7,72.0^{\circ} \mathrm{C}$ ) was applied and the reaction was started by addition of $100 \mathrm{nM}$ dNTPs. After 10 min of incubation the reactions were stopped by addition of gel loading buffer ( $80 \%$ formamide, $20 \mathrm{mM}$ EDTA). Product mixtures were separated by $12 \%$ denaturating PAGE and visualised using a Phosphorimager.

\subsection{Real time RT-PCR conditions}

Real time RT-PCR for Dobrava virus was performed as described [17] using the LightCycler $^{\circledR} 480$ RNA Master Hydrolysis Probes kit containing an aptamer blocked Tth (RT and DNA polymerase). Taq M1 was tested using the Tris $\cdot \mathrm{HCl}-\left(\mathrm{NH}_{4}\right)_{2} \mathrm{SO}_{4}$ buffer described above ( $\mathrm{pH}$ 9.2) or a bicine buffer (50 mM Bicine ( $\mathrm{pH}$ 8.2), $115 \mathrm{mM}$ $\mathrm{KOAc}, 2.5 \mathrm{mM} \mathrm{MgCl}_{2}, 8 \%$ glycerol). Primer concentrations were $500 \mathrm{nM}$ for the primers and $200 \mathrm{nM}$ for the probe and the following temperature profile of $\mathrm{RT} 63^{\circ} \mathrm{C} 5$ 
min, Activation $95^{\circ} \mathrm{C}, 1 \mathrm{~min}, 45$ cycles of 2 -step PCR $95^{\circ} \mathrm{C}, 5 \mathrm{sec}$ and $60^{\circ} \mathrm{C} 1 \mathrm{~min}$ was used for both enzymes. A transcribed quantitative RNA standard was used for sensitivity testing. All tests with the quantitative RNA standard were done in triplicates.

\subsection{Real time RT PCR using a RNA template that form stable secondary structure}

psiCHECK2 (Promega) plasmids containing either a G-quadrupex structure 5'd(GGG TGG GTG GGT GGG TGG GTG GG)-3' or a similar control sequence 5'd(GTG TGT GTG TGT GGG)-3' were kindly provided by Prof. Hartig, University of Konstanz. [18] By using primer with a 5'-overhang containing the T7 promoter sequence 5'-d(TAA TAC GAC TCA CTA TAG GGC TTG TCG AGA CAG AGA AGA CTC TTG C)-3' and the reverse primer 5'-d(CGA TGT GAG GCA CGA CGT GCC TCC)-3' a 406 respectively 398 base pair DNA fragment was generated. RNA templates with the G-quadruplex sequence 5'-(GGG UGG GUG GGU GGG UGG GUG GG)-3' or the control sequence 5'-(GUG UGU GUG UGU GGG)-3' were gained by in vitro T7 transcription. Remaining DNA was digested with DNasel and the RNA purified with the Qiagen RNeasy kit. 40 units of RiboLock ${ }^{\text {TM }}$ RNase Inhibitor were added to the RNA templates. Reaction mixtures $(20 \mu \mathrm{l})$ for Taq M1 contained $50 \mathrm{mM}$ Tris- $\mathrm{HCl}\left(\mathrm{pH}\right.$ 9.2), $16 \mathrm{mM}\left(\mathrm{NH}_{4}\right)_{2} \mathrm{SO}_{4}, 0.1 \%$ Tween 20, $2.5 \mathrm{mM} \mathrm{MgCl}, 1 \mathrm{mM} \mathrm{KCl}, 250$ $\mu \mathrm{M}$ of each dNTP, $0.5 \mathrm{nM}$ RNA-Template, $200 \mathrm{nM}$ of each primer (5'-d(GGT GTC CAC TCC CAG TTC AAT TAC AG)-3' forward, 5'-d(GCG TTT GCG TTG CTC GGG GTC GTA CAC C)-3' reverse), 0.6 x SYBRgreenl, 20 nM Taq M1 DNA polymerase. Experiments with Roche Titan one Kit were performed with the same template, primer, dNTP, SYBRgreenl and $\mathrm{KCl}$ concentrations in the supplied buffer. According to the manual DTT and enzyme mix were added. In the initial reverse transcription 
step a temperature gradient (from $55-70^{\circ} \mathrm{C}$ for $15 \mathrm{~min}$ ) was applied. The product (133/141 base pairs) was amplified in 30 PCR cycles $\left(94^{\circ} \mathrm{C}\right.$ for $2 \mathrm{~min}, 55^{\circ} \mathrm{C}$ for $30 \mathrm{sec}$ and $68^{\circ} \mathrm{C}$ for $45 \mathrm{sec}$ ) and analyzed by melting curve measurement from $30-94^{\circ} \mathrm{C}$.

\section{Results and discussion}

Previously, we discovered a thermostable DNA polymerase (KlenTaq M1) with RT PCR activity [13] by directed enzyme evolution. An overview of the mutations in the KlenTaq domain (dark blue) is shown in Figure $1 \mathrm{~A}$ on a ribbon representation of the crystal structure [19]. Here, by using the scaffold of KlenTaq M1 we constructed a full length Taq DNA polymerase (Taq M1) with the respective amino acid mutations of the KlenTaq M1. Taq M1 was over-expressed in E. coli cells and purified by Ni-NTA affinity chromatography followed by a gel filtration (see Figure 1b).

First, we tested if the mutations of KlenTaq M1 domain influence the activity of the added N-terminal attached nuclease domain. Therefore we used a stable DNA hairpin structure to which a radioactive labelled cleavage substrate anneals at the complementary site (Figure 2A). This structure harbours a displaced 5' end and a frayed 3' primer terminus and has been shown to be the preferred substrate for cleavage by the nucleases of Taq DNA polymerase and E. coli DNA polymerase I [15]. Figures 2B, $\mathrm{C}$ show the time-dependent cleavage of the $22 \mathrm{nt}$ substrate resulting in the cleaved shorter product. Taq M1 exhibits similar nuclease activity than the wild-type Taq DNA polymerase (Taq wt). Thus, it appears that the mutations in the polymerase domain have little if any effect on the nuclease activity.

Next, we investigated the PCR activity of Taq M1 compared to Taq wt (Figure 3). For this, we amplified a 100 nt long DNA template which was diluted tenfold stepwise from $1 \mathrm{nM}$ to $10 \mathrm{fM}$ concentration of template. The resulting real-time PCR amplification curves using SYBRgreen I were measured and are shown in Figure 3. 
By comparing the threshold-crossing points $(\mathrm{Ct})$ between Taq wt and Taq M1 we found very similar $\mathrm{Ct}$ values and thus the same PCR sensitivity as for Taq wt (Figure 3C).

To investigate the ability of Taq M1 for reverse-transcription (RT) in comparison with Taq wt we first conducted primer extension reactions. A 20 nucleotide $5^{\prime}-{ }^{32} \mathrm{P}$ phosphate labelled DNA primer strand was annealed to its complementary site on a 30 nt RNA template strand. As control we used the respective DNA template. We further conducted the reactions at different temperatures ranging from $60-72^{\circ} \mathrm{C}$ to find an optimal RT temperature. After 10 minutes incubation we analyzed the reaction products by denaturing PAGE. The control reaction in the presence of the respective DNA template yields with both employed enzymes the expected $31 \mathrm{nt}$ long full-length product (Figure 4, $\mathrm{C}=$ control reaction). Both enzymes add an additional nucleotide in non-templated manner as it has been observed for 3'-5'-exonuclease deficient DNA polymerases before [20-22]. On the contrary, in reactions employing the RNA template the wt enzyme extends the primer by seven nucleotides and only at temperatures below $65^{\circ} \mathrm{C}$. Surprisingly at higher reaction temperatures no extension products were visible at all. Whereas using the same reaction conditions, mutant M1 reverse transcribes the RNA template significantly more efficient and produces the full-length product. Interestingly the reverse transcription efficiency is significantly reduced at temperatures higher than $70^{\circ} \mathrm{C}$. Furthermore, by comparing the $\mathrm{RT}$ activities between the Taq M1 with the previously evolved KlenTaq M1 we observed a higher RT activity of the Taq variant which may be due to an increased processivity which is known for Taq DNA polymerases compared to their nuclease lacking variants (data not shown) [23].

Next, we performed real-time RT-PCR experiments employing the 3569 nt long RNA genome from bacteriophage MS2. The RNA template was diluted stepwise from 10 
$\mathrm{nM}$ to $10 \mathrm{fM}$. In chosen set-up a 100 nt RNA target-sequence had to be first reverse transcribed within 30 min and subsequently amplified according to a standard onestep RT-PCR protocol (Figure 5). Interestingly, we found that only the mutated Taq M1 is able to efficiently process the RNA target. Taq wt in contrast showed only low PCR activities and amplified the reverse transcribed RNA target resulting in Ct value differences of more than $\sim 10$ cycles depending on the RNA template concentration. These results corroborate previous findings of a low intrinsic RT activity of Taq DNA polymerase $[11,12]$. Inspired by the finding of the temperature dependence of RT reaction (see Figure 4) we conducted real-time RT PCR experiments at different temperatures (ranging from $60-72^{\circ} \mathrm{C}$ ) during the RT step (see Figure 6 ) and found a clear temperature dependence of the RT which is in good agreement to the previously conducted RNA primer extensions (see Figure 4). The RT optimum reaction temperature with the lowest $\mathrm{Ct}$ value is between $63-68^{\circ} \mathrm{C}$. The efficiency drastically drops when the RT temperature is below $63^{\circ} \mathrm{C}$ or higher than $70^{\circ} \mathrm{C}$.

After having obtained these promising results, we next validated these findings in the detection of pathogenic RNA obtained from natural sources in a case study. To test the performance of the newly generated TaqM1 enzyme in an established virus realtime RT-PCR TaqMan assay the enzyme was adapted for use in an assay for the detection of Dobrava virus [17]. The real time RT-PCR assay for Dobrava virus has an analytical sensitivity of $10^{2}$ molecules when using the Roche Kit containing an aptamer blocked Tth DNA polymerase. We found that the TaqM1 enzyme did not perform well in the real-time RT-PCR assay using a Tris- $\mathrm{HCl}\left(\mathrm{NH}_{4}\right)_{2} \mathrm{SO}_{4}$-based buffer (pH 9.2) employed in the previous real-time PCR and the extension assays. Better results were obtained with an analytical sensitivity of $10^{3}$ molecules in a less basic 50 $\mathrm{mM}$ bicine buffer ( $\mathrm{pH}$ 8.2). Comparison of the efficiencies of the Dobrava assays ( $\mathrm{E}$ $\left.=10^{(-1 / \text { slope })}-1\right)$ of 0.56 and 0.61 for Tth based kit and TaqM1 in bicine buffer, however 
clearly indicate that the novel TaqM1 enzyme shows a real-time RT-PCR performance comparative to the aptamer blocked Tth DNA polymerase.

Finally, we set out to investigate the ability of Taq M1 to reverse transcribe RNA targets that form stable secondary structures [18]. Therefore, we chose a well described RNA sequence, which is forming a stable G-quadruplex motif and conducted real time RT-PCR experiments in comparison with a commercial available kit (Titan One Tube RT-PCR System, Roche) that contains an enzyme mix comprising AMV reverse transcriptase $(\mathrm{RT})$ and a thermostable DNA polymerase blend (see Figure 8). Both set-ups show a strong amplification signal at standard RT temperatures $\left(55^{\circ} \mathrm{C}\right)$ using an RNA template unable to form a G-quadruplex motif, as a positive control (see Figure $8 \mathrm{a}$, left side). When applying increased RT temperatures $\left(70^{\circ} \mathrm{C}\right)$ nearly the same PCR curve is obtained for Taq $M 1$ whereas the $\mathrm{C}_{\mathrm{t}}$ value of the commercial kit increased from 7 to more than 10 indicating an inactivation of the thermosensitive AMV RT. Using the G-quadruplex forming RNA target the commercial system was neither able to amplify at standard RT temperatures (here $55^{\circ} \mathrm{C}$ ) nor at $70^{\circ} \mathrm{C}$. On the contrary, Taq $\mathrm{M} 1$ showed amplification at both temperatures. These experiments clearly demonstrate the benefits from being able to perform reverse transcription at higher temperatures by Taq M1. Thus, this novel enzyme has a high potential for the detection of secondary structure prone RNA molecules found in RNA viruses or tm-RNA in bacteria [24, 25].

\section{Concluding remarks}

We successfully combined a nuclease domain to a previously described $\mathrm{N}$-terminal shortened mutated Taq DNA polymerase [12] that has significantly increased reverse transcriptase activity without significantly compromising polymerase and nuclease function of the resulting chimera Taq M1. It is shown that Taq M1 has similar PCR 
activity as the Taq wt enzyme. Furthermore, the mutations in the polymerase domain have little effect on the activity of the attached nuclease domain. We demonstrate that Taq M1 can be used for reverse transcription of RNA targets at high temperatures $\left(\sim 60-70^{\circ} \mathrm{C}\right)$. The nuclease domain of Taq $\mathrm{M} 1$ renders this enzyme highly suitable for any probe based detection methods. We demonstrated this in the detection of RNA pathogens from natural sources. Noteworthy, without laborious optimisation of parameters comparable detection sensitivities than commercially available one-step RT-PCR systems, which are usually based on enzyme blends, were found. We think that the system might be further enhanced by optimizing reaction buffer composition, reaction conditions like $\mathrm{pH}$ and reagent concentrations. Further advancements of RNA detection by one-step RT-PCR might be feasible in particular of complex RNA targets with highly stable secondary structure motifs in which reverse transcription at high temperatures is of urgent need. The scaffold of Taq M1 could serve as the basis for further progress along these lines employing directed enzyme evolution [26-30].

Funding by the Deutsche Forschungsgemeinschaft and by project InSan M SAB1 $4 A 008$ of the BMVg is gratefully acknowledged. 


\section{References}

[1] Schmaljohn, C., Hjelle, B., Hantaviruses: a global disease problem. Emerg. Infect. Dis. 1997, 3, 95-104.

[2] Palese, P., Influenza: old and new threats. Nat. Medicine 2004, 10, 82-87.

[3] Morens, D. M., Folkers, G. K., Fauci, A. S., The challenge of emerging and reemerging infectious diseases. Nature 2004, 430, 242-249.

[4] De Paula, S. O., Fonseca, B. A., Dengue: a review of the laboratory tests a clinician must know to achieve a correct diagnosis. Braz. J. Infect. Dis. 2004, 8, 390398.

[5] Mullis, K. B., Faloona, F. A., Specific synthesis of DNA in vitro via a polymerasecatalyzed chain reaction. Methods Enzymol. 1987, 155, 335-350.

[6] Holland, P. M., Abramson, R. D., Watson, R., Gelfand, D. H., Detection of specific polymerase chain reaction product by utilizing the $5^{\prime}-3^{\prime}$ exonuclease activity of Thermus aquaticus DNA polymerase. Proc. Natl. Acad. Sci. USA 1991, 88, 72767280

[7] Strerath, M., Marx, A., Genotyping - From genomic DNA to genotype in a single tube. Angew. Chem. Int. Ed. Engl. 2005, 44, 7842-7849.

[8] Lynch, J. R., Brown, J. M., The polymerase chain reaction: current and future clinical applications. J. Med. Genet. 1990, 27, 2-7.

[9] Bustin, S. A., Mueller, R., Real-time reverse transcription PCR (qRT-PCR) and its potential use in clinical diagnosis. Clin. Sci. 2005, 109, 365-379.

[10] Nazarenko, I. A., Bhatnagar, S. K., Hohman, R. J., A closed tube format for amplification and detection of DNA based on energy transfer. Nucleic Acids Res. $1997,25,2516-2521$.

[11] Myers, T. W., Gelfand, D. H., Reverse transcription and DNA amplification by a Thermus thermophilus DNA polymerase. Biochemistry 1991, 30, 182-192. 
[12] Jones, M. D., Foulkes, N. S., Reverse transcription of mRNA by Thermus aquaticus DNA polymerase. Nucleic Acids Res. 1989, 17, 8387-8388.

[13] Sauter, K. B. M., Marx, A., Evolving thermostable reverse transcriptase activity in a DNA polymerase scaffold. Angew. Chem. Int. Ed. 2006, 45, 7633-7635.

[14] Barnes, W. M., The fidelity of Taq polymerase catalyzing PCR is improved by an N-terminal deletion. Gene 1992, 112, 29-35.

[15] Lyamichev, V., Brow, M. A. D., Varvel, V. E., Dahlberg, J. E., Comparison of the $5^{\prime}$ nuclease activities of Taq DNA polymerase and its isolated nuclease domain. Proc. Natl. Acad. Sci. USA 1999, 96, 6143-6148.

[16] Summerer, D., Rudinger, N. Z., Detmer, I., Marx, A., Enhanced DNA Polymerase Mismatch Extension Fidelity by Directed Combinatorial Enzyme Design Angew. Chem. Int. Ed. 2005, 44, 4712-4715.

[17] Weidmann, M., Schmidt, P., Vackova, M., Krivanec, K., et al., Identification of genetic evidence for dobrava virus spillover in rodents by nested reverse transcription (RT)-PCR and TaqMan RT-PCR. J. Clin. Microbiol. 2005, 43, 808-812.

[18] Halder, K., Wieland, M., Hartig, J. S., Predictable suppression of gene expression by 5'-UTR-based RNA quadruplexes. Nucleic Acids Res. 2009, epub. PMID: 19740765

[19] Li, Y., Korolev, S., Waksman, G., Crystal structures of open and closed forms of binary and ternary complexes of the large fragment of Thermus aquaticus DNA polymerase I: structural basis for nucleotide incorporation. EMBO J. 1998, 17, 7514-7525

[20] Clark, J. M., Novel non-templated nucleotide addition reactions catalyzed by procaryotic and eucaryotic DNA polymerases. Nucleic Acids Res. 1988, 16, 96779686. 
[21] Holzberger, B., Marx, A., Enzymatic synthesis of perfluoroalkylated DNA. Bioorg. Med. Chem. 2009, 17, 3653-3658.

[22] Kranaster, R., Marx, A., Taking Fingerprints of DNA Polymerases: Multiplex Enzyme Profiling on DNA Arrays. Angew. Chem. Int. Ed. Engl. 2009, 48, 4625-4628. [23] Wang, Y., Prosen, D. E., Mei, L., Sullivan, J. C., Finney, M., Vander Horn, P. B., A novel strategy to engineer DNA polymerases for enhanced processivity and improved performance in vitro. Nucleic Acids Res. 2004, 32, 1197-1207.

[24] Kuo, K. W., Leung, M. F., Leung, W. C., Intrinsic secondary structure of human TNFR-I mRNA influences the determination of gene expression by RT-PCR. Mol. Cell. Biochem. 1997, 177, 1-6.

[25] O'Grady, J., Ruttledge, M., Sedano-Balbas, S., Smith, T. J., et al., Rapid detection of Listeria monocytogenes in food using culture enrichment combined with real-time PCR. Food Microbiol. 2009, 26, 4-7.

[26] Ghadessy, F. J., Ong, J. L., Holliger, P. Directed evolution of polymerase function by compartmentalized self-replication. Proc. Natl. Acad. Sci. USA 2001, 98, $4552-4557$.

[27] Xia, G., Chen, L., Sera, T., Fa, M. et al., Directed evolution of novel polymerase activities: mutation of a DNA polymerase into an efficient RNA polymerase. Proc. Natl. Acad. Sci. USA 2002, 99, 6597-6602.

[28] Vichier-Guerre, S., Ferris, S., Auberger, N., Mahiddine, K., et al., A population of thermostable reverse transcriptases evolved from Thermus aquaticus DNA polymerase I by phage display. Angew. Chem. Int. Ed. Engl. 2006, 45, 6133-6137.

[29] Patel, P. H., Loeb, L. A., Multiple amino acid substitutions allow DNA polymerases to synthesize RNA. J. Biol. Chem. 2000, 275, 40266-40272. 
[30] Summerer, D., Rudinger, N. Z., Detmer, I., Marx, A., Enhanced fidelity in mismatch extension by DNA polymerase through directed combinatorial enzyme design. Angew. Chem. Int. Ed. Engl. 2005, 44, 4712-4715. 
((Figure Legends))

Figure 1. (A) Taq M1 mutations mapped on a ribbon representation of Taq DNA polymerase (PDB code 1TAQ, [19]). KlenTaq domain (deep blue) and nuclease domain (light blue) of Taq M1 are depicted. (B) SDS-PAGE gel of purified Taq DNA polymerases.

Figure 2. Nuclease activity (A) Hairpin structure of template and 22 nt substrate (bold). The arrow indicates the expected cleavage position based on reported studies on E. coli DNA polymerase I and Taq DNA polymerase [15]. (B) Reaction products separated by denaturing PAGE. (C) Product formation (quantified ratio of product to the sum of product and substrate) after certain time periods $(0,5,15,30,60 \mathrm{~min})$.

Figure 3. PCR activity test of Taq wt compared to Taq M1.

(A) and (B) Real-time PCR curves of a template dilutions series using Taq wt (A) and Taq M1 (B) including a negative control without template (dashed line). Generally, all reactions were performed in triplicates. (C) Ct values vs. detected DNA template molecules.

Figure 4. Reverse transcription primer extension of Taq M1 compared to Taq wt under equal reaction conditions. $M=$ Marker, reaction mix without enzyme. $C=$ control reaction with the corresponding DNA template. Incubation (10 min, $10 \mathrm{nM}$ enzyme concentration) was carried out at different temperatures ranging from 60$72^{\circ} \mathrm{C}$ (from left to right: $60.1,60.3,61.2,62.5,63.9,65.3,66.7,68.1,69.5,70.8,71.7$, $\left.72.0^{\circ} \mathrm{C}\right)$. 
Figure 5. Real-time RT PCR activity test of Taq wt compared to Taq M1.

(A) and (B) Real-time RT PCR curves of a tenfold template dilutions series with Taq wt (A) and Taq M1 (B) including a negative control without template (dashed line). Generally, reactions were performed in triplicates. (C) Ct values vs. number of RNA template molecules.

Figure 6. Temperature dependence of Taq M1 reverse transcriptase activity. Resulting Ct values of subsequent amplification vs. applied RT temperature. RT reaction (15 min incubation, $5 \mathrm{nM}$ enzyme concentration) was carried out at different temperatures ranging from $60-72^{\circ} \mathrm{C}$.

Figure 7. Dobrava virus detection by one step real-time RT PCR. Crossing points (CP) are plotted against RNA molecules detected. Each regression line was calculated from a triplicate data set.

Figure 8. Real-time RT PCR using a RNA template that forms secondary structure (G-quadruplex motif) (B) compared to a quadruplex-free control template (A). Amplification curves are deriving using Taq M1 (solid line) or a commercial kit with a reverse transcription step at $55^{\circ} \mathrm{C}$ or $70^{\circ} \mathrm{C}$ for $15 \mathrm{~min}$, respectively. 
((biot200900200-figures))

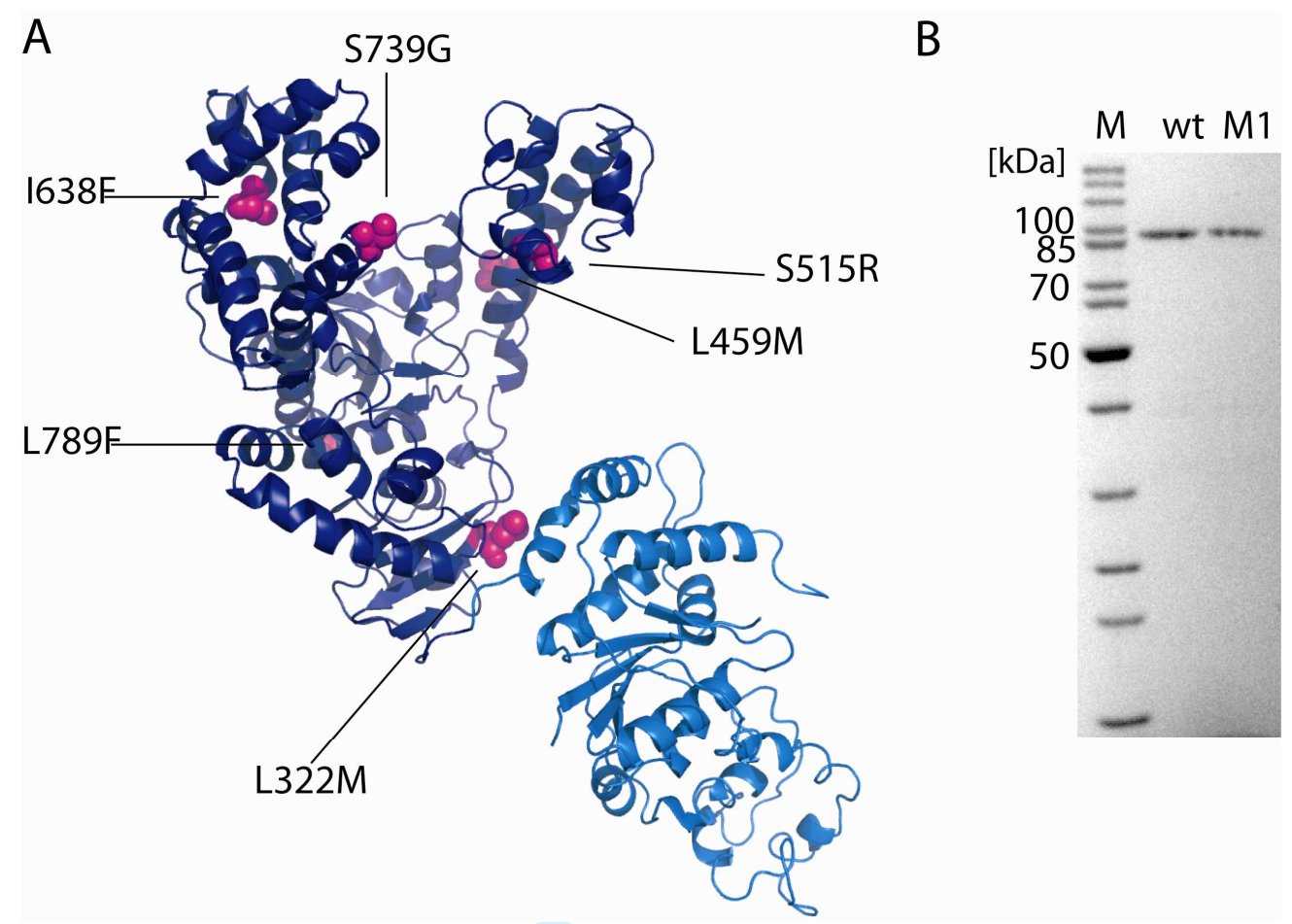

Figure 1. (A) Taq M1 mutations mapped on a ribbon representation of Taq DNA polymerase (PDB code 1TAQ, [19]). KlenTaq domain (deep blue) and nuclease domain (light blue) of Taq M1 are depicted. (B) SDS-PAGE gel of purified Taq DNA polymerases. 
A

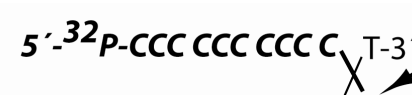

A A GaC CAg tTC ATC GGC taC CTG CAT Ga TCAT ACG TAC AC-3.

A $_{G}$ CTG GTC AAG TAG CCG ATG GAC GTA CTA GTA TGC ATG TG-5'

B

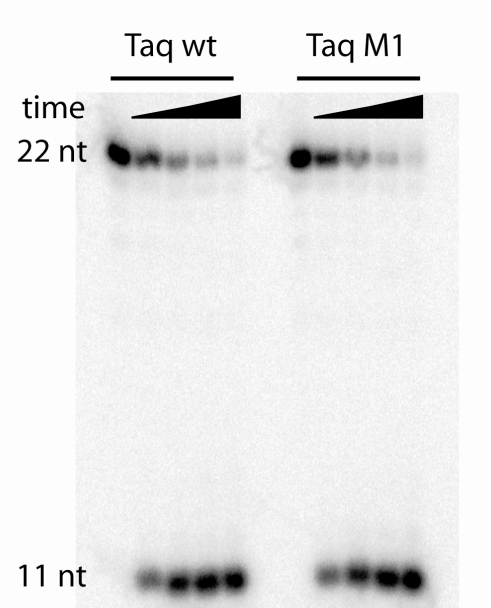

C

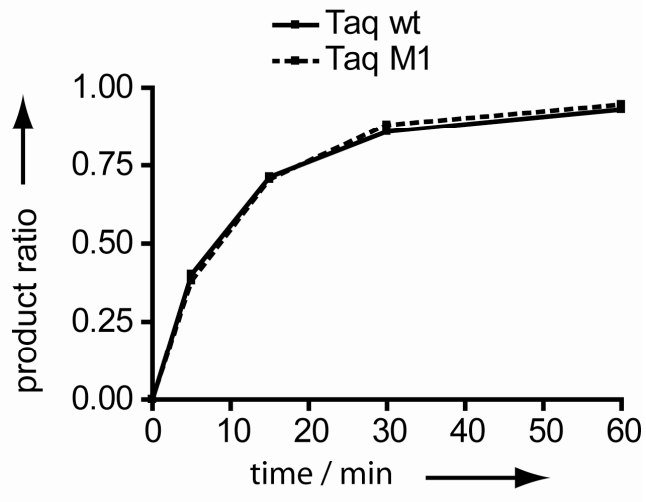

Figure 2. Nuclease activity (A) Hairpin structure of template and 22 nt substrate (bold). The arrow indicates the expected cleavage position based on reported studies on E. coli DNA polymerase I and Taq DNA polymerase [15]. (B) Reaction products separated by denaturing PAGE. (C) Product formation (quantified ratio of product to the sum of product and substrate) after certain time periods (0, 5, 15, 30, $60 \mathrm{~min})$. 
A

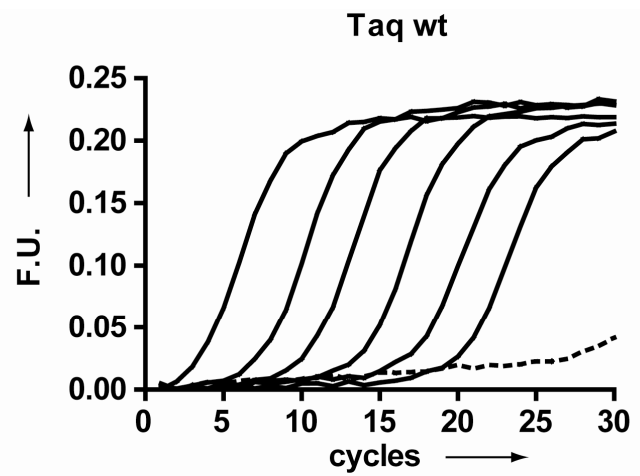

B

Taq M1

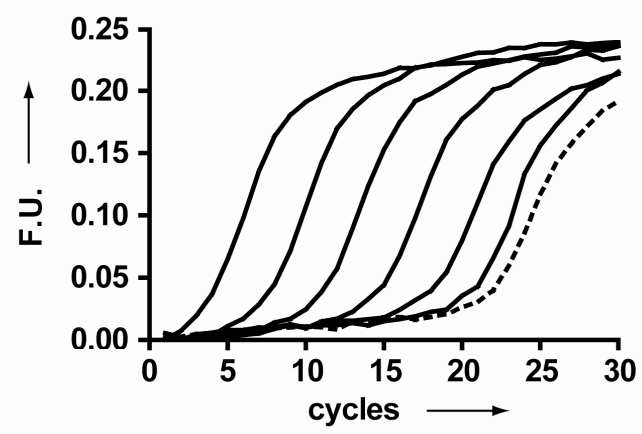

C

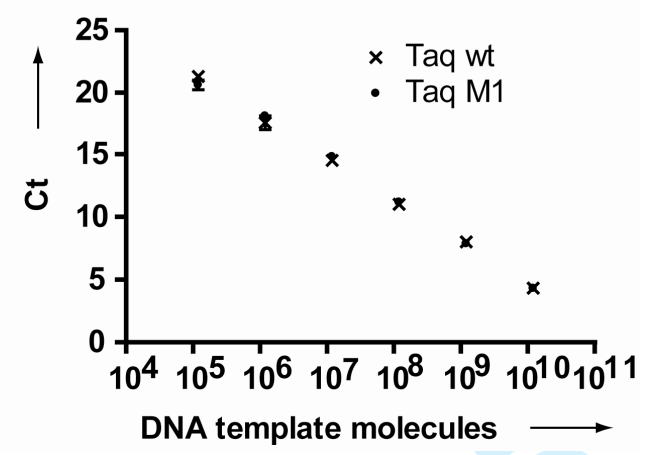

Figure 3. PCR activity test of Taq wt compared to Taq M1.
(A) and (B) Real-time PCR curves of a template dilutions series using Taq wt (A) and Taq M1 (B) including a negative control without template (dashed line). Generally, all reactions were performed in triplicates. (C) Ct values vs. detected DNA template molecules. 

3 4 5 6 7

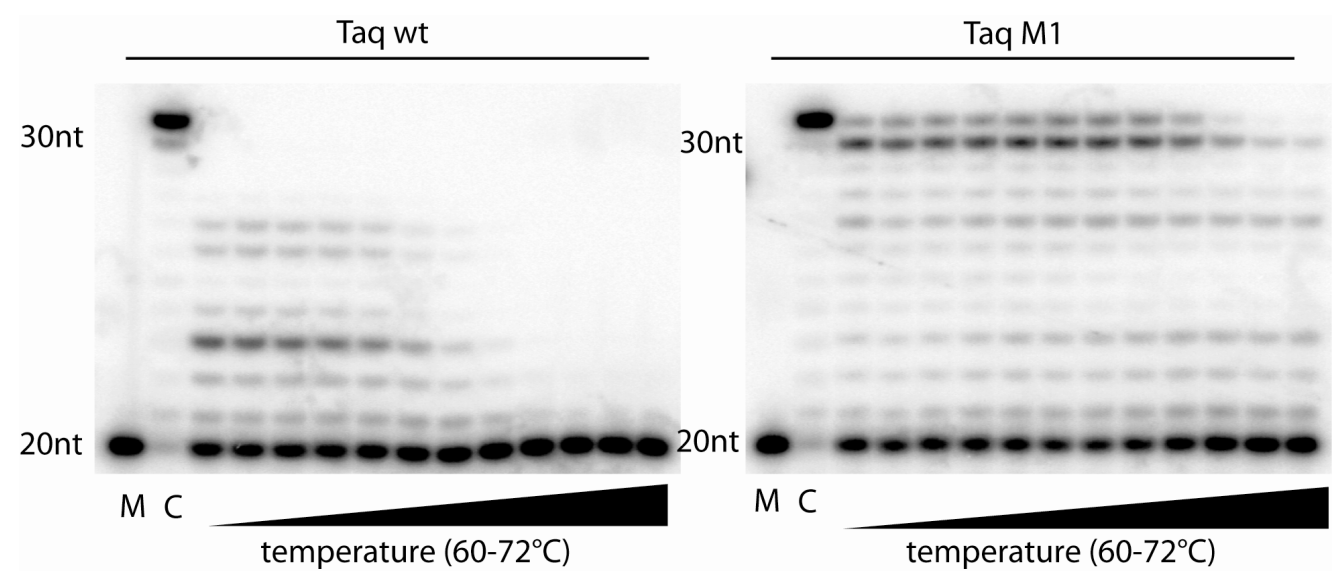

Figure 4. Reverse transcription primer extension of Taq M1 compared to Taq wt under equal reaction conditions. $M=$ Marker, reaction mix without enzyme. $C=$ control reaction with the corresponding DNA template. Incubation (10 min, $10 \mathrm{nM}$ enzyme concentration) was carried out at different temperatures ranging from 60$72^{\circ} \mathrm{C}$ (from left to right: $60.1,60.3,61.2,62.5,63.9,65.3,66.7,68.1,69.5,70.8,71.7$, $\left.72.0^{\circ} \mathrm{C}\right)$. 


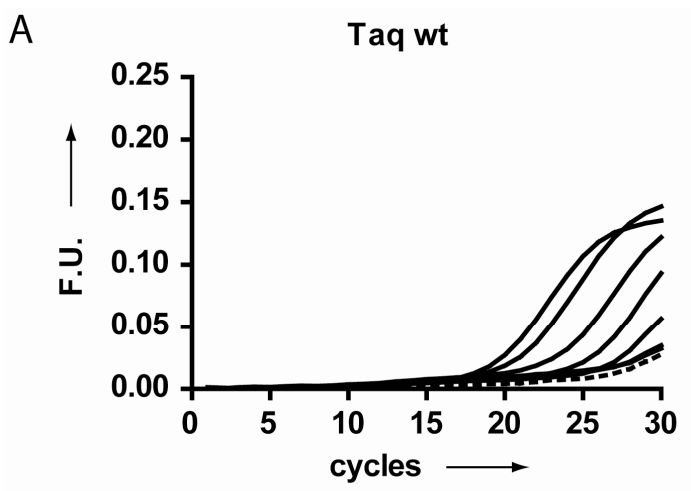

B

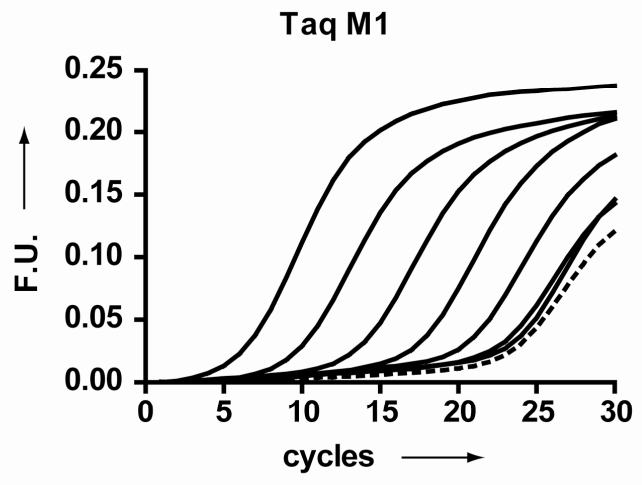

C

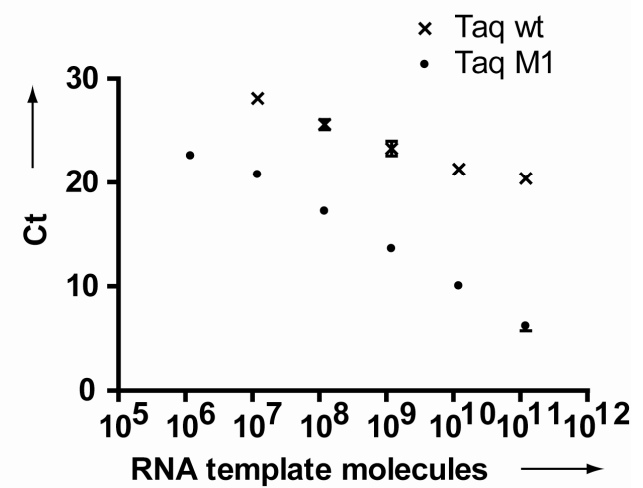

Figure 5. Real-time RT PCR activity test of Taq wt compared to Taq M1.

(A) and (B) Real-time RT PCR curves of a tenfold template dilutions series with Taq wt $(\mathrm{A})$ and Taq M1 (B) including a negative control without template (dashed line). Generally, reactions were performed in triplicates. (C) Ct values vs. number of RNA template molecules. 


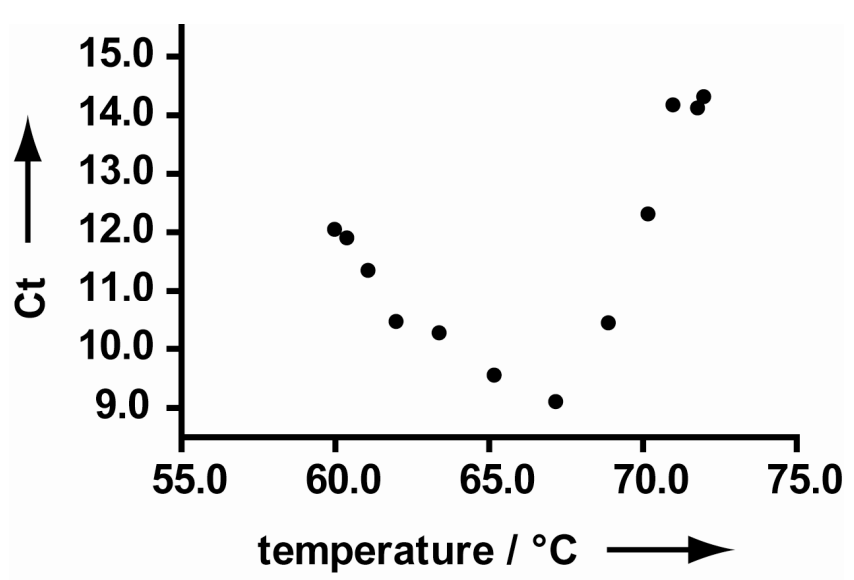

Figure 6. Temperature dependence of Taq M1 reverse transcriptase activity.

Resulting Ct values of subsequent amplification vs. applied RT temperature. RT reaction (15 min incubation, $5 \mathrm{nM}$ enzyme concentration) was carried out at different temperatures ranging from $60-72^{\circ} \mathrm{C}$. 


\section{Dobrava Real time PCR}

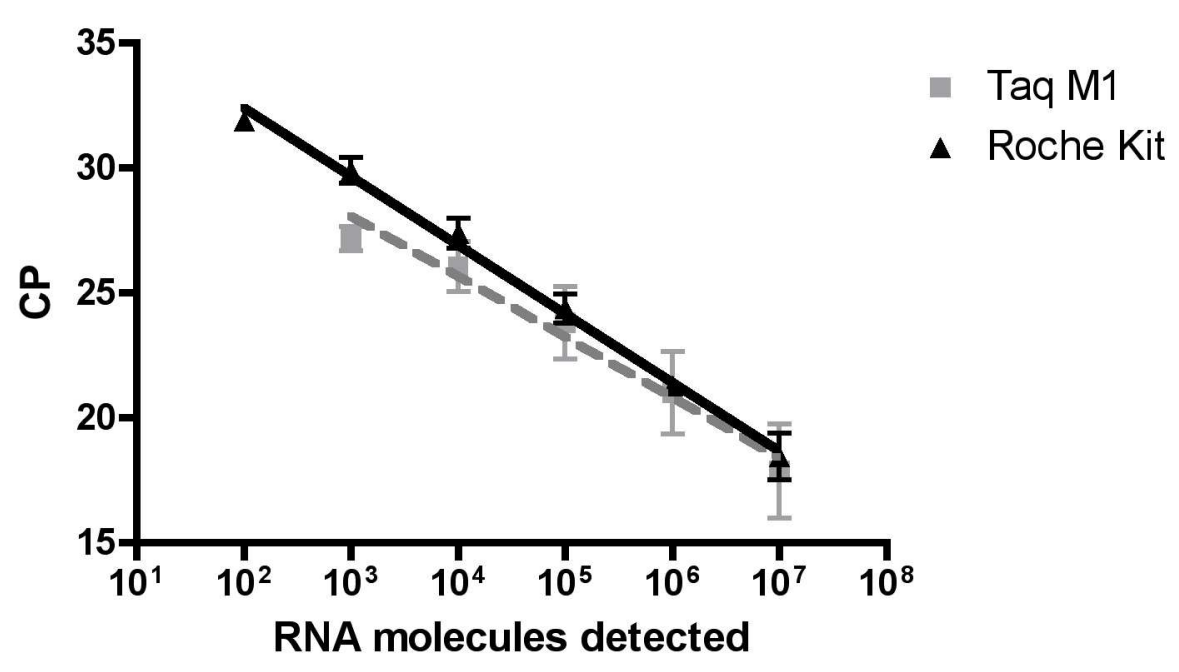

Figure 7. Dobrava virus detection by one step real-time RT PCR. Crossing points (CP) are plotted against RNA molecules detected. Each regression line was calculated from a triplicate data set. 
A

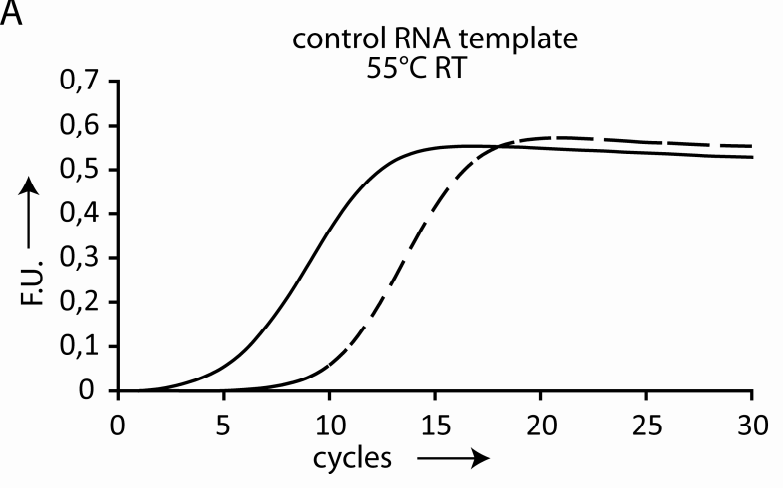

B

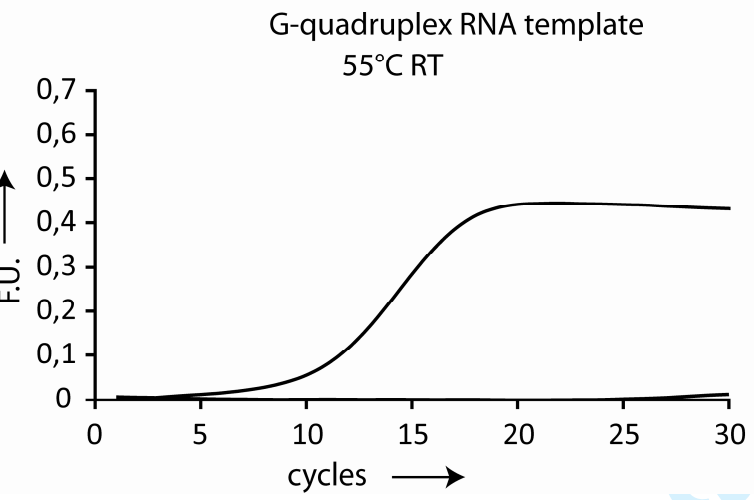

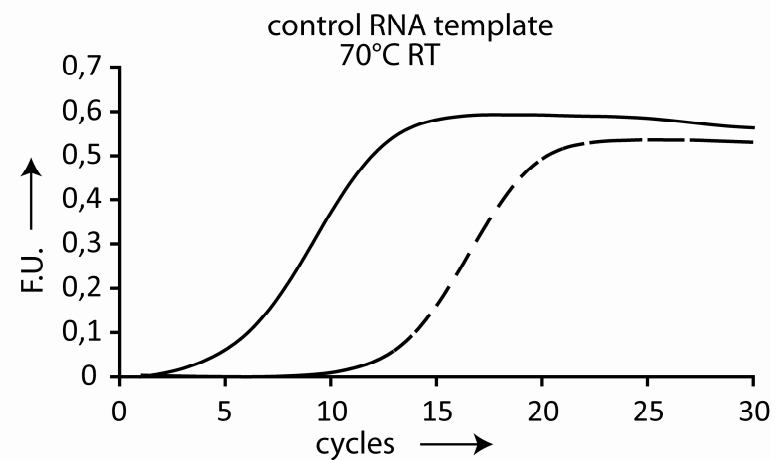

Taq M1

Titan One

G-quadruplex RNA template $70^{\circ} \mathrm{CRT}$

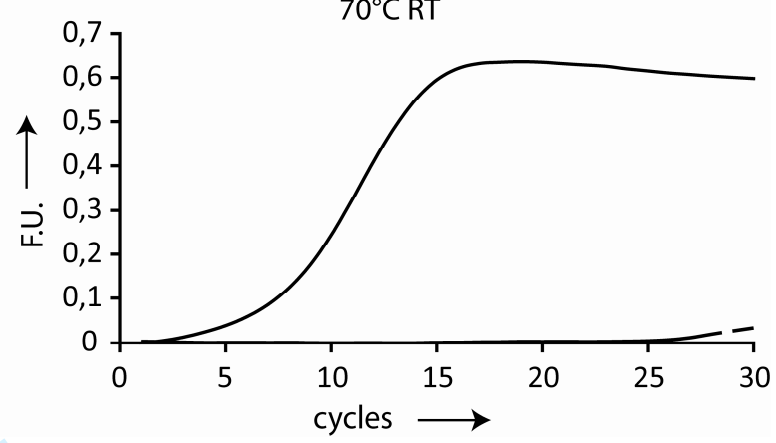

Figure 8. Real-time RT PCR using a RNA template that forms secondary structure (G-quadruplex motif) (B) compared to a quadruplex-free control template (A). Amplification curves are deriving using Taq M1 (solid line) or a commercial kit with a reverse transcription step at $55^{\circ} \mathrm{C}$ or $70^{\circ} \mathrm{C}$ for $15 \mathrm{~min}$, respectively. 